\title{
TRIPLE MODEL OF AUDITORY SENSORY PROCESSING: A NOVEL GATING STREAM DIRECTLY LINKS PRIMARY AUDITORY AREAS TO EXECUTIVE PREFRONTAL CORTEX
}

\author{
Sanja Josef Golubić \\ Department of Physics, Faculty of Science, University of Zagreb, Zagreb, Croatia
}

\begin{abstract}
SUMMARY - The generally accepted model of sensory processing of visual and auditory stimuli assumes two major parallel processing streams, ventral and dorsal, which comprise functionally and anatomically distinct but interacting processes in which the ventral stream supports stimulus identification, and the dorsal stream is involved in recognizing the stimulus spatial location and sensori-motor integration functions. However, recent studies suggest the existence of a third, very fast sensory processing pathway, a gating stream that directly links the primary auditory cortices to the executive prefrontal cortex within the first 50 milliseconds after presentation of a stimulus, bypassing hierarchical structure of the ventral and dorsal pathways. Gating stream propagates the sensory gating phenomenon, which serves as a basic protective mechanism preventing irrelevant, repeated information from recurrent sensory processing. The goal of the present paper is to introduce the novel 'three-stream' model of auditory processing, including the new fast sensory processing stream, i.e. gating stream, alongside the well-affirmed dorsal and ventral sensory processing pathways. The impairments in sensory processing along the gating stream have been found to be strongly involved in the pathophysiological sensory processing in Alzheimer's disease and could be the underlying issue in numerous neuropsychiatric disorders and diseases that are linked to the pathological sensory gating inhibition, such as schizophrenia, post-traumatic stress disorder, bipolar disorder or attention deficit hyperactivity disorder.
\end{abstract}

Key words: Sensory processing; Dorsal stream; Ventral stream; Gating stream; Dual model of sensory processing; Triple model of sensory processing; Alzheimer's disease; Schizophrenia; Post-traumatic stress disorder; Attention-deficit/hyperactivity disorder

\section{Cortical Sensory Processing}

Processing of external sensory stimuli is a fundamental feature of any living system. Sensory processing has an integral role in interaction and adaptation, by which the individual navigates through a stimulusloaded environment. Although intensive research of sensory processing has accumulated a large body of

Correspondence to: Sanja Josef Golubic, $P h D$, Department of Physics, Faculty of Science, University of Zagreb, Bijenička cesta 32, HR-10000 Zagreb, Croatia

E-mail: sjg.android@gmail.com

Received July 11, 2018, accepted October 9, 2018 knowledge over years, the key issues such as where, when and how the human neural system processes, integrates and influences environmental information to produce personal experiences and an image of reality, are still not well understood. The widely accepted twostream hypothesis reveals dual pathways of processing for both visual and auditory stimulus: the 'where' and 'what' pathways or dorsal and ventral processing streams, respectively ${ }^{1-7}$. It has been demonstrated that these two pathways comprise functionally and anatomically distinct but probably interacting processes in which the ventral stream supports stimulus recognition and identification, and dorsal stream is involved in 
recognizing the stimulus spatial location relative to the subject along with sensorimotor integration functions $^{2,8}$. It is suggested that dorsal and ventral pathways have hierarchical processing architecture by which feedforward connections convey sensory information from 'the bottom to the top' and also provide infrastructure for strong feedback connections returning processed information from 'the top to the bot-

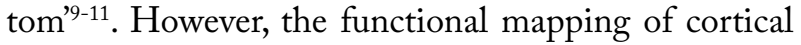
sensory processing pathways remains an ongoing quest. Recent neuroimaging studies investigating the spatio-temporal characteristic of the early auditory sensory processing provide strong evidence for the existence of a third, very fast sensory processing stream that directly links the executive prefrontal brain centers with the primary sensory areas ${ }^{12-16}$. This novel processing stream supports the phenomenon known as sensory gating. Sensory gating is the core feature of a neural system to automatically adjust its response to subsequent stimuli; in the gating-out mode selectively suppresses its responses to irrelevant or repeated information, while in the gating-in mode enhances responses to the task relevant or novel sensory information. Sensory gating impairments, in addition to deficits in the top-down regulation of attentional resources, have been found to be strongly involved in pathophysiological sensory processing in schizophrenia, as well as in several other neuropsychiatric disorders and diseases such as post-traumatic stress disorder (PTSD), bipolar disorder or attention deficit/hyperactivity disorder (ADHD). The goal of the present paper is to introduce the novel 'triple-stream' model of auditory processing, presenting the third sensory processing stream, i.e. gating stream, which directly connects the executive prefrontal cortex to the primary auditory cortices, alongside the well-affirmed dorsal and ventral sensory processing pathways (Fig. 1).

\section{Methods for Studying Human Sensory Processing}

Noninvasive study of the human sensory processing relies on modern functional neuroimaging techniques, preferably with both high temporal and spatial resolutions. Functional magnetic resonance imaging (fMRI), positron emission tomography (PET), singlephoton emission computed tomography (SPECT) and near-infrared spectroscopy (NIRS) are neuroim-

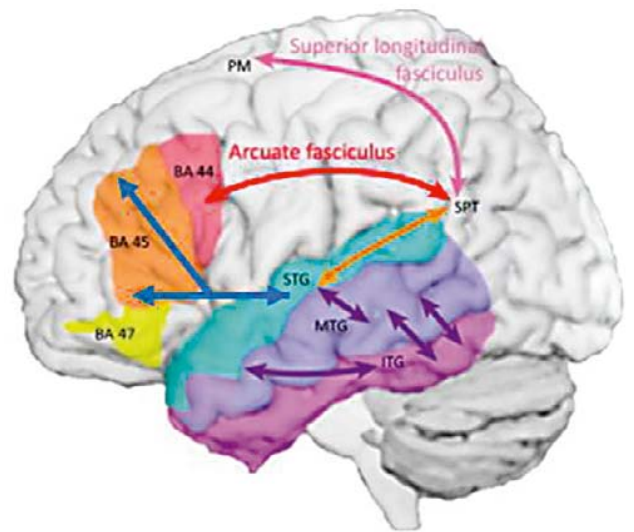

GATING STREAM $\longleftrightarrow$ DORSAL STREAM $\longleftrightarrow$ VENTRAL STREAM $\longleftrightarrow$

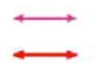

Fig. 1. Triple-stream model of auditory sensory processing. Auditory sensory processing system, from primary auditory area (STG), diverges into three processing streams: gating stream, which is in charge of producing the gating phenomena; ventral stream, which is involved in mapping auditory stimulus onto meaning; and dorsal stream, which is involved in mapping auditory stimulus onto articulatory-based representations. MTG = middle temporal gyrus; STG = superior temporal gyrus; ITG = inferior temporal gyrus; STS = superior temporal sulcus; $\mathrm{PM}=$ premotor frontal cortex; BA $44=$ Brodmann area 44 ; BA 45 = Brodmann area $45 ; \mathrm{BA} 47=$ Brodmann area 47

aging techniques that enable an indirect look at the neural system during processing of sensory stimulus ${ }^{17,18}$. These techniques are based on metabolic and vascular signals that are assumed to be linearly correlated to neuronal activity, although a reliable functional relationship is not yet established. Temporal resolution of these neuroimaging techniques is on a minute scale, low compared to underlying brain activity which is spanning 1-3 ms of action potential firing to a few tens of milliseconds of synchronous synaptic activity of thousands of postsynaptic neurons, which can be recorded extracranially.

However, electroencephalography (EEG) and magnetoencephalography (MEG) are functional neuroimaging techniques that enable direct measuring the brain electromagnetic activity. EEG and MEG are both sensitive to the electrochemical currents within and between brain cells and can capture the dynamics of neural responses elicited by a simple sensory stimulus with the millisecond temporal resolution. Such 
sensory responses last a few to several hundred milliseconds. EEG and MEG are completely noninvasive and provide complementary information on the underlying electromagnetic brain activity. MEG measures the magnetic field generated by the primary currents through postsynaptic dendrites, while EEG measures the voltage scalp distribution generated by the secondary extracellular ionic flow. MEG advantage over EEG lies in higher accuracy and resolution of spatial localization of neural substrate underlying the recorded electromagnetic activity. Spatial resolution of EEG on a centimeter scale is similar to that of conventional $\mathrm{fMRI}^{19}$, and substantially lower than the millimeter spatial resolution and accuracy of $\mathrm{MEG}^{20-}$ 22. Widely accepted assumption that MEG detects only sources that are tangential to the scalp surface is one of the main disadvantages associated with the technique. However, recent studies have shown that source orientation is not a significant factor in limiting MEG sensitivity ${ }^{22,23}$. Using both numerical simulation and empirical measurements, it has been shown that the source depth and spatial extent of activated assembly on the convoluted cortical surface are the main factors that compromise the sensitivity of MEG to neural activity in the human cortex ${ }^{22}$. Moreover, the authors have demonstrated that MEG can detect a very low amplitude dipole current source in the deep tissue of the prefrontal cortex, which is simultaneously active with the several times higher magnitude dipole sources in the superficial regions of the primary sensory areas $^{12}$. Therefore, MEG is the first choice for noninvasive spatio-temporal localization of the neural substrate which underlies processing of the sensory inputs and reconstruction of the associated sensory networks.

\section{General Organization of Sensory Processing}

Hierarchical organization is widely assumed to be the key architectural principle of the sensory processing $^{24,25}$. Hierarchical mode of processing has been first established in the visual system, where lower, primary areas receive visual input and higher areas perform a multimodal associational role. The hierarchy in sensory processing is based on the neurobiological differences between the forward and backward connections found in the activated cortical layers ${ }^{25,26}$. The forward links start in the superficial pyramidal cells of the lower cortex and preferably complete on the stellate cells of layer 4 in the higher cortical domains ${ }^{25,27}$. The backward links start from the deep pyramidal cells in the infragranular layers and link the cells in the supragranular layers of the lower cortex. This model of sensory processing implies the primary sensory areas to be activated first, within the first $100 \mathrm{~ms}$ after sensory input; subsequently, the multimodal and associative areas of the cortex conjoin simultaneously received inputs from distinct sensory modes and limbic system; and finally about 250 ms post-stimulus, the higher cortical areas, placed largely in the prefrontal brain areas, perform final interpretation of the data received from diverse sensory streams.

\section{Neurophysiology of auditory processing}

Numerous neuroimaging studies conducted in humans have revealed different cortical areas underlying auditory sensory processing, generally dividing these functions along the posterior medial-anterior lateral axis $^{6,28-30}$. The early cortical stages of auditory processing start at the primary auditory-responsive fields in the bilateral superior temporal gyri (STG) during the first $30 \mathrm{~ms}$ post-stimulus. This auditory sensory processing system then diverges into three processing streams, i.e. the gating stream, which is in charge of producing the gating phenomena ${ }^{31}$; the ventral stream, which is involved in the mapping auditory stimulus onto meaning; and the dorsal stream, which is involved in the mapping auditory stimulus onto articulatorybased representations ${ }^{9,30}$, as shown in Figure 1. The gating stream processes sensory information very fast, within the first $50 \mathrm{~ms}$ after stimulus presentation ${ }^{12}$, while both ventral and dorsal processing are slower, extending through $250 \mathrm{~ms}$ post-stimulus to complete perception ${ }^{9}$.

\section{Ventral auditory processing stream}

Studies investigating the structure and organization of the auditory cortex have revealed that the ventral (what) stream projects ventro-laterally through the cortex spreading along the anterior-lateral-temporal to the inferior-frontal axis. Ventral stream involves the portions of the middle temporal gyrus (MTG) and the posterior inferior temporal sulcus where the complex sounds are converted into semantic words. Afterwards, the inferior temporal gyrus (ITG) processes distributed semantic information into conceptual representa- 
tion through two-step combinatorial sets ending at the inferior frontal gyrus (IFG) ${ }^{29,32}$.

\section{Dorsal auditory processing stream}

The dorsal (where) stream projects from the primary auditory areas across inferior parietal regions to the more posterior regions of the prefrontal cortices compared with ventral stream projections ${ }^{33}$. The dorsal stream projects dorso-posteriorly toward the parietal lobe and finally to the frontal regions comprising the posterior STG, the posterior superior temporal sulcus (STS) and the inferior parietal lobule (IPL) ${ }^{32,34-36}$. The critical dorsal region is placed within the posterior parts of sylvian fissure at the boundary between the parietal and temporal lobes ${ }^{37,38}$. The dorsal stream appears to end at the lateral prefrontal cortex (PFC) and the superior frontal sulcus (SFS). Together, these regions comprise a distributed network for spatial auditory processing ${ }^{39-41}$.

\section{Gating auditory processing stream}

Recent MEG studies suggest the existence of a third, very fast sensory processing pathway, the gating stream that directly links primary auditory cortices to the executive PFC within the first 50 milliseconds after presentation of an auditory stimulus ${ }^{12-15}$. The existence of a direct pathway between PFC and primary auditory areas is anatomically supported by reports of dense bidirectional connections between the PFC and the superior temporal cortices in the primate and human anatomic studies ${ }^{42,43}$. The dorsal sensory processing stream terminates in the dorso-lateral PFC (dlP$\mathrm{FC}$ ), which is the convergence point of many corticocortical pathways, implying its function as a crossmodal point of association ${ }^{44}$. An important aspect of the dIPFC is that it is highly interconnected with the motor and primary sensory cortices and especially with all PFC areas. The orbitofrontal cortex (OFC) and medial PFC also share extensive cortico-cortical connections, including extensive local projections to and from other prefrontal regions, as well as with the motor, limbic and sensory cortices ${ }^{45}$. The structural properties of the connecting pathways provide the means for the primary sensory areas and prefrontal regions to work together as a gating network via fast sensory gating stream.

Contrary to the hierarchical model of sensory processing, Josef Golubic et al. demonstrated a direct top- down modulatory role of the PFC on the primary auditory areas as a mechanism underlying pre-perceptive auditory sensory gating ${ }^{12}$. In addition, their novel results provide evidence that the fast gating stream influenced by attention diverges at the prefrontal cortex into the dorso-lateral (dlPFC) and medial prefrontal (mPFC) branches (Fig. 1) $)^{13,15}$. Passive listening of tone provokes activation of the dlPFC, while both voluntary directing attention and automatic, stimuli driven initiation of attentional involvement in sensory processing activate the $\mathrm{mPFC}$ during sensory gating ${ }^{12,13,15}$. The fast gating stream enables the PFC to apply the top-down attentional control during the earliest stage of sensory processing but also rapid initiation of the bottom-up stimulus driven attentional involvement, demonstrating that both top-bottom and bottom-up connections are critical for attention and working memory ${ }^{13,15,46}$.

\section{Clinical Importance of the Gating Processing Stream}

The impairments in the auditory gating inhibition have been associated with numerous neurological and neuropsychiatric diseases and disorders such as Alzheimer's disease $(\mathrm{AD})^{46}$, bipolar disorder ${ }^{47}$, post-traumatic stress disorder ${ }^{48,49}$, Parkinson's disease ${ }^{50}$, Huntington's disease ${ }^{51}$, depression ${ }^{52}$ and schizophrenia ${ }^{53}$. While in both fundamental and clinical research, it has long been assumed that the primary auditory cortices are the central areas for producing the auditory gating inhibition, the discovery of a fast gating pathway that directly links the prefrontal cortex and primary auditory areas, with an integral role in producing the sensory gating ${ }^{12}$, strongly challenges this hypothesis.

Given that the sensory gating stream enables formation of the gating phenomenon, the impairments in sensory processing along the novel, fast gating pathway could be the key issues underlying neurological and neuropsychological diseases and disorders associated with deficiency in auditory gating. The very recent results, which promote the absence of auditory processing along the novel gating stream as the first neurophysiological sign of $\mathrm{AD}^{12,14}$, support this assumption. The work by Josef Golubic et al. shows that the healthy auditory processing is characterized by the prefrontal gating activation in response to both novel and repeating tone of an oddball paradigm, demon- 
strating normal processing along the gating stream. To the contrary, their results reveal that the symptomatic $\mathrm{AD}$ stage is characterized by the lack of any prefrontal gating activation to either deviant or repeating tone, suggesting the absolute failure of auditory processing along the gating stream. Moreover, their results indicate that a putative pre-clinical stage of AD is characterized by the absence of the prefrontal gating activation to the repeating tone only, while the prefrontal activation to the novel tone is still preserved, thus showing the first measurable impairments of sensory processing along the gating stream. Discovered modulation of processing along the fast gating stream shows a high potential as an individual biomarker for the detection of $\mathrm{AD}$, which may provide a unique opportunity to detect physiological changes associated with the disease before symptoms occur, i.e. during a putative preclinical stage.

However, the interpretation of the wide range of extracranially measured modulation of the gating inhibition in different pathophysiology requires the establishment of both top-down and bottom-up cortical dynamics along the gating stream in healthy individuals. Such normative data will imply the opportunity to identify changes in the dynamics of the prefrontal gating activity related to the various pathologies, enabling more reliable diagnosis and treatment testing.

\section{Triple Model of Sensory Processing}

Novel data challenge the actual dual stream model of sensory processing, suggesting the triple stream model, with one fast and two concurrent parallel anatomic pathways for processing of sensory information. This review provides evidence for the triple sensory pathway concept that assumes three major parallel processing streams which connect the primary auditory cortices with the executive frontal areas, i.e. a direct, fast and pre-perceptive gating stream and two long streams, directed above (dorsal) or below (ventral) the sylvian fissure ${ }^{32}$. According to this concept, the fast gating stream serves as a basic protective mechanism preventing irrelevant, repeated information from recurrent sensory processing (gating-out), while at the same time enabling recognition of relevant environment inputs that are essential for survival (gating-in). This fast connection enables the executive PFC to apply the top-down attentional control during the earli- est stage of sensory processing but also rapid initiation of the bottom-up stimulus driven attentional involvement. Slower ventral and dorsal pathways both have the ability to process information on the intrinsic properties of stimuli and their spatial characteristic, but the transformations performed upon those features differ across streams ${ }^{54-56}$. Given that the modulations of gating inhibition are linked to numerous neurophysiological diseases and disorders, discovery of the fast sensory gating stream on which the sensory gating phenomenon relies promises to help illuminate the pathophysiology of these clinical conditions.

\section{References}

1. Ungerleider LG, Mishkin M. Two cortical visual systems. In: Ingle DJ, Goodale MA, Mansfield, RJW, editors. Analysis of Visual Behavior. Cambridge, Massachusetts: MIT Press; 2002. p. 549-86. DOI: 10.1016/0166-2236(83)90190-X

2. Milner AD, Goodale, MA. The Visual Brain in Action. Oxford: Oxford University Press, 1995. DOI: 10.1093/acprof:o so/9780198524724.001.0001

3. Rauschecker JP. Cortical processing of complex sounds. Curr Opin Neurobiol. 1998;8:516-21. DOI: 10.1016/s0959-4388 (98)80040-8

4. Bushara KO, Weeks RA, Ishii K, Catalan MJ, Tian B, Rauschecker JP, et al. Modality-specific frontal and parietal areas for auditory and visual spatial localization in humans. Nat Neurosci. 1999;2(8):759-66. DOI: 10.1038/11239

5. Recanzone GH. Spatial processing in the auditory cortex of the macaque monkey. Proc Natl Acad Sci U S A. 2000;97:1182935. DOI: 10.1073/pnas.97.22.11829

6. Maeder PP, Meuli RA, Adriani M. Distinct pathways involved in sound recognition and localization: a human fMRI study. Neuroimage. 2001;14:802-16. DOI: 10.1006/nimg.2001.0888

7. Recanzone GH. Representation of con-specific vocalizations in the core and belt areas of the auditory cortex in the alert macaque monkey. J Neurosci. 2008;28:13184-93. DOI: 10.1523/jneurosci.3619-08.2008

8. Hickok G, Poeppel D. Dorsal and ventral streams: a framework for understanding aspects of the functional anatomy of language. Cognition. 2004; 92:67-99. DOI: 10.1016/j.cognition.2003.10.011

9. Fuster JM. Network memory. Trends Neurosci. 1997;1144 (10):451-9.DOI: 10.1016/S0166-2236(97)01128-4

10. Mesulam MM. From sensation to cognition. Brain. 1998; 121(6):1013-52. DOI: 10.1093/brain/121.6.1013

11. Huntenburg JM, Bazin PL, Margulies DS. Large-scale gradients in human cortical organization. Trends Cogn Sci. 2017; 22(1):21-31. DOI: 10.1016/j.tics.2017.11.002 
12. Josef Golubic S, Aine CJ, Stephen JM, Adair JC, Knoefel JE, Supek S. Modulatory role of the prefrontal generator within the auditory M50 network. Neuroimage. 2014;92:120-31. DOI: 10.1016/j.neuroimage.2014.02.013

13. Josef Golubic S, Susac A, Huonker R, Haueisen J, Supek S. Early attentional modulation of the neural network evoked with the auditory paired-click paradigm: an MEG study. Procedia Soc Behav Sci. 2014;126:195-6. DOI: 10.1016/j.sbspro.2014.02.368

14. Josef Golubic S, Aine CJ, Stephen JM, Adair JC, Knoefel JE, Supek S. MEG biomarker of Alzheimer's disease: absence of a prefrontal generator during auditory sensory gating. Hum Brain Mapp. 2017;38(10):5180-94. DOI: 10.1002/hbm.23724

15. Josef Golubic S, Jurasic MJ, Susac A, Huonker R, Gotz T, Haueisen J.Attention modulates topology and dynamics of auditory sensory gating. Hum Brain Mapp. 2019;40(10):298194. DOI: $10.1002 / \mathrm{hbm} .24573$

16. Josef Golubić S. Topological biomarker of Alzheimer's disease. In: Begum G, editor. Biomarker - Indicator of Abnormal Physiological Process. London, United Kingdom: IntechOpen. 2018; pp. 169-93. DOI: 10.5772/intechopen.76633

17. Prpić I, Ahel T, Rotim K, Gajski D, Vukelić P, Sasso A. The use of neuroimaging in the management of chronic headache in children in clinical practice versus clinical practice guidelines. Acta Clin Croat. 2014;53(4): 449-54. https://hrcak.srce. $\mathrm{hr} / 136781$

18. Đorić I, Žarković M, Radojičić Z, Repac N, Janićijević A, Rotim K, et al. The value of multidetector computed tomography of orbits in globe protrusion in comparison to Hertel exophthalmometry. Acta Clin Croat. 2017;56:21-7. DOI: 10.20471/ acc.2017.56.01.04

19. Michel CM, Murray MM, Lantz G, Gonzalez S, Spinelli L, Grave de Peralta R. EEG source imaging. Clin Neurophysiol. 2004;115(10):2195-222. DOI: 10.1016/j.clinph.2004.06.001

20. Supek S, Stingl K, Josef Golubic S, Susac A, Ranken D. Optimal spatio-temporal matrix subdivision for cortical neurodynamics estimation. In: Proceedings of the $15^{\text {th }}$ International Conference on Biomagnetism (BIOMAG 2006), Vancouver, 2006; p. 180-5.

21. Baillet S, Mosher JC, Leahy RM. Electromagnetic brain mapping. IEEE Signal Process Mag. 2001;18:14-30. DOI: $10.1109 / 79.962275$

22. Josef Golubic S, Susac A, Grilj V, Ranken D, Huonker R, Haueisen J, Supek S. Size matters: MEG empirical and simulation study on source localization of the earliest visual activity in the occipital cortex. Med Biol Eng Comput. 2011;49: 545-54. DOI: $10.1007 /$ s11517-011-0764-9

23. Hillebrand A, Barnes GR. A quantitative assessment of the sensitivity of whole-head MEG to activity in the adult human cortex. Neuroimage. 2002; 16:638-50. DOI: 10.1006/nimg. 2002.1102

24. Zeki S, Shipp S. The functional logic of cortical connections. Nature. 1988;335:311-31. DOI: 10.1038/335311a0.
25. Felleman DJ, Van Essen DC. Distributed hierarchical processing in the primate cerebral cortex. Cereb Cortex. 1991;1:1-47. DOI: $10.1093 /$ cercor/1.1.1

26. Angelucci A, Levitt JB, Walton EJ, Hupe JM, Bullier J, Lund JS. Circuits for local and global signal integration in primary visual cortex. J Neurosci. 2002;22:8633-46. DOI: 10.1523/ JNEUROSCI.22-19-08633.2002

27. DeFelipe J, Alonso-Nanclares L, Arellano JI. Microstructure of the neocortex, comparative aspects. J Neurocytol. 2002;31:299316. DOI: $10.1023 / \mathrm{a}: 1024130211265$

28. Ahveninen J, Huang S, Nummenmaa A, Belliveau JW, Hung $\mathrm{AY}$, Jääskeläinen IP, et al. Evidence for distinct human auditory cortex regions for sound location versus identity processing. Nat Commun. 2013;4:2585. DOI: 10.1038/ncomms3585.

29. Alain C, Arnott SR, Hevenor S, Graham S, Grady CL. "What" and "where" in the human auditory system. Proc Natl Acad Sci U S A. 2001;98(21):12301-6. DOI: 10.1073/pnas.211209098

30. Hart HC, Palmer AR, Hall DA. Different areas of human nonprimary auditory cortex are activated by sounds with spatial and nonspatial properties. Hum Brain Mapp. 2004;21(3):17890. DOI: $10.1002 / \mathrm{hbm} .10156$

31. Josef Golubic S. Neurodynamics of normal and pathologychanged sensory processing. Dissertation. Faculty of Science, University of Zagreb, Zagreb, 2014; pp. 1-175.

32. Arnott SR, Binns MA, Grady CL, Alain C. Assessing the auditory dual-pathway model in humans. Neuroimage. 2004; 22:401-8. DOI: 10.1016/j.neuroimage.2004.01.014

33. Skipper JI, Nusbaum HC, Small SL. Lending a helping hand to hearing: another motor theory of speech perception. In: M. Arbib (Ed.). Action to Language via the Mirror Neuron System. 2006; pp. 250-86. Cambridge: Cambridge University Press. DOI: 10.1017/CBO9780511541599

34. Harrington IA, Stecker GC, Macpherson EA, Middlebrooks JC. Spatial sensitivity of neurons in the anterior, posterior, and primary fields of cat auditory cortex. Hear Res. 2008;240: 22-41. DOI: 10.1016/j.heares.2008.02.004

35. Rinne T, Ala-Salomaki H, Stecker GC, Patynen J, Lokki T. Processing of spatial sounds in human auditory cortex during visual, discrimination and 2-back tasks. Front Neurosci. 2014; 8:220. DOI: $10.3389 /$ fnins.2014.00220

36. Stecker GC, Harrington IA, Middlebrooks JC. Location coding by opponent neural populations in the auditory cortex. PLoS Biol.2005;3(3):e78.DOI: 10.1371/journal.pbio.0030078

37. Buchsbaum B, Hickok G, Humphries C. Role of left posterior superior temporal gyrus in phonological processing for perception and production. Cogn Sci. 2001;25:663-78. DOI: 10.1207/ s15516709cog2505_2

38. Hickok G, Buchsbaum B, Humphries C, Muftuler T. Auditory-motor interaction revealed by fMRI: speech, music, and working memory in area. Spt.J Cogn Neurosci. 2003;15(5):67382. DOI: $10.1162 / 089892903322307393$

39. Ahveninen J, Jaaskelainen IP, Raij T, Bonmassar G, Devore S, Hamalainen $\mathrm{M}$, et al. Task-modulated "what" and "where" 
pathways in human auditory cortex. Proc Natl Acad Sci U S A. 2006;103:14608-13. DOI: 10.1073/pnas.0510480103

40. Bizley JK, Cohen YE. The what, where and how of auditoryobject perception. Nat Rev Neurosci. 2013;14(10):693-707. DOI: $10.1038 / \mathrm{nrn} 3565$

41. Krumbholz K, Eickhoff SB, Fink GR. Feature- and objectbased attentional modulation in the human auditory "where" pathway. J Cogn Neurosci. 2007; 19(10):1721-33. DOI: 10.1162/jocn.2007.19.10.1721

42. Barbas H, Ghashghaei H, Dombrowski SM, Rempel-Clower NL. Medial prefrontal cortices are unified by common connections with superior temporal cortices and distinguished by input from memory-related areas in the rhesus monkey. J Comp Neurol. 1999;410:343-67. DOI: 10.1002/(sici)10969861(19990802)410:3<343::aid-cne1>3.0.co;2-1

43. Croxson PL, Johansen-Berg H, Timothy EJ, Behrens M, Robson D, Pinsk MA, et al. Quantitative investigation of connections of the prefrontal cortex in the human and macaque using probabilistic diffusion tractography. J Neurosci. 2005;25:885466. DOI: 10.1523/jneurosci.1311-05.2005

44. Fuster JM, Bodner M, Kroger JK. Cross-modal and cross-temporal association in neurons of frontal cortex. Nature. 2001; 405:347-51. DOI: $10.1038 / 35012613$

45. Cavada C, Company T, Tejedor J, Cruz-Rizzolo RJ, ReinosoSuarez F. The anatomical connections of the macaque monkey orbitofrontal cortex. Cereb Cortex. 2000:10:220-42. DOI: 10.1093/cercor/10.3.220

46. Supek S, Josef Golubić S, Bryant J, Donahue C, Montaño R, Adair J, et al. Neuromagnetic auditory activity reflects differences between normal aging, $\mathrm{MCI}$ and $\mathrm{AD}$ subjects: an oddball study. Proceedings of the $16^{\text {th }}$ International Conference on Biomagnetism (BIOMAG 2008). Kakigi, K, Yokosawa, K, Kuriki, S, editors. Sapporo: Hokkaido University Press 2008; pp. 171-3.

47. Wang Y, Feng Y, Jia Y, Wang W, Xie Y, Guan Y, et al. Auditory M50 and M100 sensory gating deficits in bipolar disorder: a
MEG study. J Affect Disord. 2014;15:131-8. DOI: 10.1016/j. jad.2013.08.010

48. Neylan TC, Fletcher DJ, Lenoci M, McCallin K, Weiss DS, Schoenfeld FB, et al. Sensory gating in chronic posttraumatic stress disorder: reduced auditory P50 suppression in combat veterans. Biol Psychiatry. 1999;46(12):1656-64.DOI: 10.1016/ s0006-3223(99)00047-5

49. Habek D, Dujaković T, Čerkez Habek J, Jurković I. Twentythree-year long-term health outcome after the war in Vukovar. Acta Clin Croat. 2016;55:58-62. DOI: 10.20471/ acc.2016.55.01.9

50. Teo C, Rasco L, Al-Mefty K, Skinner RD, Boop FA, GarciaRill E. Decreased habituation of midlatency auditory evoked responses in Parkinson's disease. Mov Disord. 1997;12:655-64. DOI: $10.1002 / \mathrm{mds} .870120506$

51. Uc EY, Skinnerc RD, Rodnitzkyb RL, Garcia-Rill E. The midlatency auditory evoked potential P50 is abnormal in Huntington's disease. J Neurol Sci. 2003;212:1-5. DOI: 10.1016/ S0022-510X(03)00082-0

52. Garcia-Rill E, Skinner RD, Clothire J, Dornhoffer J, Uc E, Fann A, et al. The sleep state-dependent midlatency auditory evoked P50 potential in various disorders. Thal Rel Syst. 2002;2:9-19. DOI: 10.1017/S1472928802000328

53. Adler LE, Hoffer LJ, Griffith J, Waldo MC, Freedman R. Normalization by nicotine of deficient auditory sensory gating in the relatives of schizophrenics. Biol Psychiatry. 1992;32:60716. DOI: 10.1016/0006-3223(92)90073-9

54. Weiller C, Bormann T, Saur D, Musso M, Rijntjes M. How the ventral pathway got lost: and what its recovery might mean. Brain Lang. 2011;118:29-39. DOI: 10.1016/j.bandl.2011. 01.005

55. Rijntjes M, Weiller C, Bormann T, Musso M. The dual loop model: its relation to language and other modalities. Front Evol Neurosci. 2012;4:9. DOI: 10.3389/fnevo.2012.00009

56. Lambon Ralph MA. Neurocognitive insights on conceptual knowledge and its breakdown. Phil Trans R Soc B. 2014; 369(1634):20120392. DOI: 10.1098/rstb.2012.0392 


\section{Sažetak}

\section{TRI PUTA OBRADE SLUŠNIH PODRAŽAJA: NOVI 'GATING PUT' IZRAVNO POVEZUJE PRIMARNA OSJETNA PODRUČJA S IZVRŠNIM PREFRONTALNIM KORTEKSOM}

\section{S. Josef Golubić}

Trenutno prihvaćeni model obrade vidnih i slušnih podražaja unutar velikog mozga pretpostavlja dva velika usporedna osjetna puta, ventralni i dorzalni, koji obuhvaćaju funkcionalno i anatomski različite, ali ne i međusobno isključive mehanizme kojima se obrađuju pojedina svojstva osjetne informacije. Ventralni put ima ključnu ulogu u identifikaciji sadržaja informacije, dok je dorzalni prvenstveno uključen u prostornu lokalizaciju izvora podražaja i percepciju kretanja. Međutim, nova neurofiziološka istraživanja ukazuju na postojanje trećeg, vrlo brzog puta procesiranja podražaja, "gating puta" koji izravno povezuje primarna osjetna područja s prefrontalnim dijelovima moždane kore već unutar prvih 50 milisekunda od izlaganja podražaju, na taj način zaobilazeći hijearhijski ustroj dorzalnog i ventralnog puta. Gating put omogućava brzo generiranje osjetnog gating efekta koji služi kao temeljni, pred-perceptivni zaštitni mehanizam s ulogom sprječavanja opetovane obrade ponovljene i/ili nevažne osjetne informacije. Namjera ovoga preglednog rada je predstavljanje novog "trostrukog modela" paralelnih putova obrade osjetnih informacija uvođenjem trećeg, vrlo brzog puta, gating puta, uz dva klinički već široko prihvaćena, ventralni i dorzalni. O kliničkoj važnosti novoga gating puta svjedoče najnoviji rezultati koji pokazuju da su poremećaji u gating procesiranju duž novoga osjetnog puta ključni u otkrivanju Alzheimerove bolesti, s potencijalom da otkriju neurofiziološke znakove bolesti i u predkliničkoj fazi. Patološke promjene u osjetnom procesiranju duž novootkrivenoga gating puta mogli bi biti uzroci niza neuropsiholoških i neuroloških bolesti i stanja koja su vezana uz promjene u inhibiciji neuralnog odgovora na ponovljeni podražaj (gating poremećaj), poput shizofrenije, poslijetraumatskog stresnog poremećaja ili poremećaja hiperaktivnosti i deficita pažnje.

Ključne riječi: Osjetno procesiranje; Osjetni gating put; Ventralni put; Dorzalni put; Trostruki model osjetnog procesiranja; Alzheimerova bolest; Shizofrenija; Poslijetraumatski stresni poreméaj; Poreméaj hiperaktivnosti i deficita pažnje 